Management, Procurement and Law Volume 170 Issue MP2

Briefing: The role of human values in behavioural safety

Manu, Gibb, Manu, Bell and Allen
Proceedings of the Institution of Civil Engineers

Management, Procurement and Law 170 April 2017 Issue MP2

Pages 49-51 http://dx.doi.org/10.1680/jmapl. 16.00047

Paper 1600047

Received 20/12/2016 Accepted 14/02/2017

Published online 17/03/2017

Keywords: health \& safety/safety \& hazards

\title{
Briefing: The role of human values in behavioural safety
}

1 Patrick Manu BSc (Hons), PGCert, PhD, ICIOB, FHEA Senior Lecturer, University of the West of England, Bristol, UK (corresponding author: patrick.manu@uwe.ac.uk) (Orcid:0000-0001-7766-8824)

2 Alistair Gibb BSc, PhD, CEng, MICE, MCIOB $\mathrm{ECI}$ Royal Academy of Engineering Professor of Complex Project Management, Loughborough University, Loughborough, UK
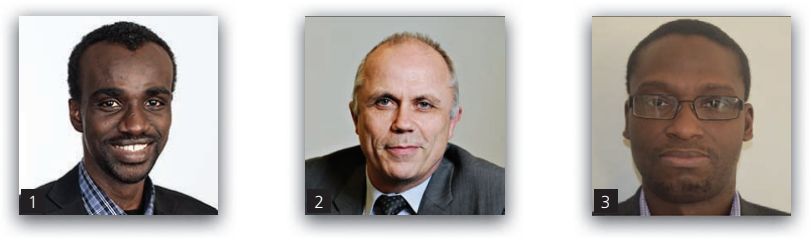

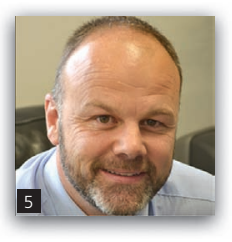

While behaviour-based safety (BBS) is not new and is even becoming increasingly common, particularly among large construction organisations, research on BBS and hence its implementation has paid limited attention to the role of innate drivers of behaviour, particularly human values (e.g. individual worker values). It is argued in this paper that there is a need for empirical studies in this area towards the generation of fresh insight that could be valuable for designing more robust interventions for strengthening BBS programmes.

\section{Introduction}

Occupational safety and health (OSH) is a concern in the industrial sectors of many countries around the world. In the construction sector, the concern is even greater as many occupational injuries, deaths and illnesses are recorded within the industry. For instance, it has been reported that in the Australian construction industry there is an average of 46 compensated fatalities per year (Lingard et al., 2010) and, in the USA, this sector accounts for about $21 \%$ of all occupational deaths from injuries (Hallowell and Gambatese, 2009). Like these countries and several others, the UK construction sector also has an unenviable reputation in terms of $\mathrm{OSH}$ performance. This paper highlights the state of OSH in the UK construction industry, the role of behaviour-based safety (BBS) as part of OSH improvement efforts and the need for more research into BBS, focusing on the potential effect of individual worker values on safe work behaviour.

\section{OSH in the UK construction industry and the role of BBS}

Accidents are relatively commonplace on construction sites in the UK, resulting in human tragedies such as deaths, injuries and illnesses (HSE, 2014). Associated with these tragedies are economic costs such as fines and costs from prosecution, claims on employers, insurance, damage to buildings and equipment or vehicles, expenditure on medical care, costs of investigation and costs from disruption of construction processes and delayed progress (Hughes and Ferrett, 2011). It is estimated that the annual economic cost resulting from injuries and illnesses in UK construction is $c$. $£ 1$ billion (HSE, 2014). Beyond the economic costs are also social costs such as the pain and suffering of affected workers, lowering of employee morale, determent of workers from entering the industry and the emotional and psychological impacts on the friends, families and co-workers of affected workers (De Saram and Tang, 2005).

Although improvements have been recorded over the past decades, injury and ill health statistics (see HSE (2014)) show that the current situation still leaves much to be desired. The acknowledgement of this need for further improvement is evident from common industry initiatives and straplines such as 'target zero', 'incident and injury free' and 'one death is too many' taken from the Donaghy (2009) report for the UK government. Efforts to address the $\mathrm{OSH}$ problem in the industry have been widespread, covering legislation, government initiatives and non-government industry-wide initiatives (Hughes and Ferrett, 2011). As understanding of the factors responsible for injuries, deaths and illnesses is crucial to the development and implementation of sound policies and measures across the industry, numerous $\mathrm{OSH}$ studies have been conducted. These studies have shown that while construction accident causation is complex, two broad causal factors are often at play: proximal factors (including behaviour/ unsafe acts by front line workers) and latent/underlying factors attributable to management/organisational and other preconstruction factors (Haslam et al., 2005; Manu et al., 2010).

While it is understood that the direct cause of many incidents is unsafe acts, it is also known that these acts can be triggered by latent failures that are distant in time and/or space from the incidents 
(Gibb et al., 2006; Manu et al., 2012). Removing or mitigating latent failures is thus important in addressing unsafe acts by front-line operatives and consequently minimising accidents in the work environment. Over the years, this has led to advances in engineering and safety management system controls/measures targeting latent failures not just during the physical construction phase but during the design and planning phase (see Manu et al. (2013), Ove Arup and Partners and Gilbertson (2007) and Zhang and $\mathrm{Hu}$ (2011)). While these developments have not led to an abandonment of direct efforts aimed at addressing unsafe acts by front-line operatives, it is evident from the construction OSH management literature that efforts targeting latent failures have been more prominent. Central to the efforts aimed at redressing unsafe acts by front-line operatives has been the BBS approach, which seeks to change unsafe behaviour of operatives (Anderson, 2005; Lees and Austin, 2011). Indications in the literature point to increasing attention on BBS (Sherratt and Farrell, 2011; Talabi et al., 2015). For instance, many large contractors with established safety management systems are implementing BBS programmes to further drive down incidents and accidents (Sherratt and Farrell, 2011; Talabi et al., 2015). Changes made to the industry's workers safety certification test (i.e. the Construction Skills Certificate Scheme test) to incorporate behavioural issues also attest to the growing attention on behavioural safety (CITB-ConstructionSkills, 2012). Finneran and Gibb (2013) also suggest that in developed regions like the UK, there is a need to pay attention to innovative OSH improvement efforts such as BBS in order to drive down incidences and accidents in construction.

Previous studies have shown that a BBS approach using interventions to modify behaviour can be useful in improving OSH. This applies not only to construction but also to other industries (Anderson, 2005; Duff et al., 1994; Lunt et al., 2008). This approach has, however, not always been successful in improving safety (Anderson, 2005; Lingard and Rowlinson, 1998). While these mixed findings should not completely rule out the pursuit of BBS programmes, they bring to question the efficacy of how BBS is implemented, particularly the interventions used in achieving and sustaining behavioural change. Interventions that have sought to change the OSH behaviour of workers have taken limited cognisance of intrinsic human factors that could affect behaviour. A study by Sherratt and Farrell (2011) hinted that such factors ought not to be overlooked in BBS programmes. Arguably, the success of BBS programmes relies on an insight into the significant drivers of workers' OSH behaviour, some of which could be intrinsic. However, despite the plethora of evidence showing that human values affect behaviour, their effect on construction workers' OSH behaviour has not received much attention in the BBS agenda, particularly at the research front.

Studies in psychology have shown significant relationships between human values and key behaviours including interpersonal co-operation, voting behaviour, readiness for social contact with members of an out-group, political activism, opposition to immigration and environmental behaviour (Schultz et al., 2005; Schwartz, 2009). These studies provide sufficient justification for further empirical studies into BBS taking into account the potential effect of human values as an intrinsic antecedent of OSH behaviour. An insight into this relationship could be invaluable for OSH, not only in construction but also in other industrial sectors. Indeed, such insight could have far-reaching implications for designing more effective behavioural safety interventions that take into account intrinsic drivers of OSH behaviour. As sustaining behaviour change remains a key challenge in implementing behavioural safety programmes (Lunt et al., 2008; Sherratt and Farrell, 2011), insight into the potential effect of human values (an intrinsic behavioural driver) on OSH behaviour could be invaluable in designing interventions that can help in achieving sustained behavioural change. To this end, empirical studies that explore the predictive potency of workers' values on their OSH behaviour are encouraged.

\section{Conclusion}

Undeniably, OSH improvement is needed in the construction industry and, as part of efforts to achieve this, there is increasing attention on BBS to drive down incidents and accidents. To entrench the utility of BBS further, it is imperative that more research is undertaken to understand what role established intrinsic drivers of behaviour, such as human values, play in OSH behaviour. It is envisaged that research in this domain could help develop more effective BBS interventions.

\section{REFERENCES}

Anderson M (2005) Behavioural safety and major accident hazards: magic bullet or shot in the dark? Process Safety and Environmental Protection 83(2): 109-116, http://dx.doi.org/10.1205/psep.04230.

CITB-ConstructionSkills (2012) Health Safety and Environmental Test for Operatives and Specialists, 8th edn. CITB-ConstructionSkills, London, UK.

De Saram DD and Tang S (2005) Pain and suffering costs of persons in construction accidents: Hong Kong experience. Construction Management and Economics 23(6): 645-658, http://dx.doi.org/ 10.1080/01446190500039739.

Donaghy R (2009) One Death Is Too Many - Inquiry into the Underlying Causes of Construction Fatal Accidents. The Stationery Office, Norwich, UK, Report to the Secretary of State for Work and Pensions - Report Cm 7657.

Duff AR, Robertson RA, Phillips RA and Cooper MD (1994) Improving safety by the modification of behaviour. Construction Management and Economics 12(1): 67-78, http://dx.doi.org/10.1080/ 01446199400000008.

Gibb AGF, Haslam R, Gyi DE, Hide S and Duff R (2006) What causes accidents? Proceedings of the Institution of Civil Engineers - Civil Engineering 159(6): 46-50, http://dx.doi.org/10.1680/cien.2006. 159.6.46.

Finneran A and Gibb A (2013) W099 - Safety and Health in Construction Research Roadmap - Report for Consultation. Conseil International du Bâtiment General Secretariat, Delft, the Netherlands, CIB Publication 376.

Hallowell MR and Gambatese JA (2009) Activity-based safety risk quantification for concrete formwork construction. Journal of Construction Engineering and Management 135(10): 990-998, http:// dx.doi.org/10.1061/(ASCE)CO.1943-7862.0000071.

Haslam RA, Hide SA, Gibb AGF et al. (2005) Contributing factors in construction accidents. Applied Ergonomics 36(4): 401-415, http://dx. doi.org/10.1016/j.apergo.2004.12.002. 
Management, Procurement and Law

Volume 170 Issue MP2
Briefing: The role of human values in

behavioural safety

Manu, Gibb, Manu, Bell and Allen
HSE (Health and Safety Executive) (2014) Health and Safety in Construction in Great Britain, 2014. HSE, London, UK. See http://www.cirruspurchasing.co.uk/constructionRIDDOR2015.pdf (accessed 20/07/2016).

Hughes P and Ferrett E (2011) Introduction to Health and Safety in Construction, 4th edn. Routledge, Abingdon, UK.

Lees $\mathrm{H}$ and Austin J (2011) The case for behaviour-based safety in construction. Proceedings of the Institution of Civil Engineers Management, Procurement and Law 164(1): 3-8, http://dx.doi.org/10. 1680/mpal900074.

Lingard H and Rowlinson S (1998) Behaviour-based safety management in Hong Kong's construction industry: the results of a field study. Construction Management and Economics 16(4): 481-488, http://dx.doi.org/10.1080/014461998372259.

Lingard HC, Cooke T and Blismas N (2010) Safety climate in conditions of construction subcontracting: a multi-level analysis. Construction Management and Economics 28(8): 813-825, http://dx.doi.org/10. 1080/01446190903480035.

Lunt J, Bates S, Bennett V and Hopkinson J (2008) Behaviour Change and Worker Engagement Practices within the Construction Sector. HSE Books, Sudbury, UK Research Report RR660, pp. 1-271.

Manu P, Ankrah N, Proverbs D and Suresh S (2010) An approach for determining the extent of contribution of construction project features to accident causation. Safety Science 48(6): 687-692, http://dx.doi.org/ 10.1016/j.ssci.2010.03.001.

Manu P, Ankrah N, Proverbs D and Suresh S (2012) Investigating the multicausal and complex nature of the accident causal influence of construction project features. Accident Analysis and Prevention 48: 126-133, http://dx.doi.org/10.1016/j.aap.2011.05.008.
Manu P, Ankrah N, Proverbs D and Suresh S (2013) Mitigating the health and safety influence of subcontracting in construction: the approach of main contractors. International Journal of Project Management 31(7): 1017-1026, http://dx.doi.org/10.1016/j.ijproman.2012.11.011.

Ove Arup and Partners and Gilberson A (2007) CDM Regulations - Work Sector Guidance for Designers, 3rd edn. Construction Industry Research and Information Association, London, UK.

Schultz PW, Gouveia VV, Cameron LD et al. (2005) Values and their relationship to environmental concern and conservation behavior. Journal of Cross-Cultural Psychology 36(4): 457-475, https://doi.org/ $10.1177 / 0022022105275962$.

Schwartz SH (2009) Basic human values. Proceedings of Cross-national and Comparison Seminar on Quality and Comparability of Measures for Constructs in Comparative Research: Methods and Applications, Bolzano, Italy.

Sherratt F and Farrell P (2011) Behavioural and cultural safety programmes: evaluation from the UK site perspective. Proceedings of CIB W099 2011 Conference, Washington, DC, USA.

Talabi BO, Gibb AGF and Edum-Fotwe FT (2015) Behaviour-based safety (BBS): a construction industry's perspective. In Proceedings of $C I B$ W099 International Health and Safety Conference: Benefiting Workers and Society through Inherently Safe(r) Construction (Behm M and McAleenan C (eds)). EEI Publishing, Belfast, Ireland, pp. 181-190.

Zhang J and Hu Z (2011) BIM-and 4D-based integrated solution of analysis and management for conflicts and structural safety problems during construction: 1. Principles and methodologies. Automation in Construction 20(2): 155-166, http://dx.doi.org/10.1016/j.autcon.2010. 09.013 .

\section{How can you contribute?}

To discuss this paper, please email up to 500 words to the editor at journals@ice.org.uk. Your contribution will be forwarded to the author(s) for a reply and, if considered appropriate by the editorial board, it will be published as discussion in a future issue of the journal.

Proceedings journals rely entirely on contributions from the civil engineering profession (and allied disciplines).

Information about how to email your paper online is available at www.icevirtuallibrary.com/page/authors, where you will also find detailed author guidelines. 